\title{
Performance Evaluation of a Maize Cob Thresher
}

\author{
Adeyi Abdulrasaq Mashood, Willoughby Fouad Ayinde, Shehu Muhammed Yusuf, Ola Olalekan Abiola and \\ Faleye Tope \\ National Centre for Agricultural Mechanization (NCAM), Farm Power \& Machinery Department, KM 20, Ilorin-Lokoja High Way \\ Idofian, P.M.B. 1525, Ilorin Kwara State, Nigeria
}

\begin{abstract}
Threshing is one of the most critical parts of post-harvest operation which affects the quality and quantity of maize production. It could be done manually or mechanically. However, the objective of this study was to evaluate the performance of a maize cob thresher fabricated at National Centre for Agricultural Mechanization (NCAM) Ilorin at three different moisture contents and analyze the result using ANOVA and bar chart as statistical tools. The average values of parameters evaluated at three different stages of moisture content (15.81\%, 16.79\% and 17.10\%) of maize cob are as follow: threshing capacity $754.20,737.38$ and $720.23 \mathrm{~kg} / \mathrm{h}$; threshing efficiency 99.73\%, 99.63\% and 99.16\%; cleaning efficiency $89.82 \%$, $89.45 \%$ and $88.34 \%$; broken grains ratio $0.84 \%$, $0.79 \%$ and $0.70 \%$; time taken 43, 44 and $45 \mathrm{~s}$, respectively. The total amount of maize cob fed into the machine was $9 \mathrm{~kg}$ in three replicates for each of the moisture content and the average values of threshed maize of 8.08, 8.05 and $7.95 \mathrm{~kg}$ was recovered, respectively. There was significant difference in threshing efficiency, amount of chaffs in the threshed maize and the percentage broken ration. At 17.10\% moisture content, the percentage broken grain ratio was minimal. At high moisture content, more force, energy and time is required to thresh certain amount of maize cob. Also, at minimal moisture content less force and energy is required for maximum output. Therefore, considering the previous work on performance evaluation of maize cob thresher, this machine performed satisfactorily and is far better than manual method. The machine is effective, efficient, affordable and available for the small and medium scale farmers in Nigeria.
\end{abstract}

Key words: Maize cob, thresher, performance evaluation, moisture.

\section{Introduction}

Maize (Zea mays L.) is one of the most important and widely distributed cereals crop in the world after wheat and rice. It is used as staple food for human consumption, feed for animals and serves as industrial raw materials for products like syrup, alcohol, acids, etc. Maize is a rich source of starch and other nutrients beneficial to both human and animal health. Some nutritional values of maize are starch (60.38\%-66.31\%), protein (10.82\%-13.59\%), oil content (4.16\%-5.76\%) and the amount of carbohydrate is between $63.03 \%$ and $69.36 \%$ [1]. Every country in the world produces maize for different purposes. In year 2010 world ranking, the United States was followed by China in maize production with 177 million metric tons (MMT)

Corresponding author: Faleye Tope, M. Eng., research fields: tillage and agricultural machinery system design and testing.
Brazil 56 MMT, Mexico 23 MMT and Argentina 21 MMT [2]. In year 2016, the total maize production in the world is 1,060,107,470 million tons in which Nigeria produced 10.4 million tons [3]. An increase in Nigeria population has greatly increased the consumption of maize either fresh or in milled form by the citizens which made an improved maize production and processing techniques inevitable to increase its production quality and the quantity.

The stages required in maize production include land preparation, planting, fertilizer application, weeding, harvesting, drying, de-husking, threshing, milling, packaging and storage. The processing of agricultural products like maize into quality forms not only prolongs the useful life of these products but also increases the net profit of the farmers through the use of mechanization processing technologies [4]. The quality of maize is determined by the use of suitable threshing techniques. One of the most important processing operations done to bring out the quality of 
maize is threshing and grinding of maize [5]. Maize threshing is a post-harvest operation which could be done either manually or mechanically. The manual method is tedious, time consuming and expensive. Majority of the farmers in Nigeria employ manual method, which has a great implication on their health and income. However, the objective of this work was to carry out performance evaluation of a motorized maize cob thresher at three different moisture contents that is capable of reducing drudgery, time of operation, save cost of production and improve the source of income of Nigeria farmers.

\section{Materials and Methods}

\subsection{Description of the Machine}

The thresher consists of hopper, threshing unit, which comprises shaft, threshing drum and beater; sieve, grain delivery chute, cobs and chaffs outlet, blower and the prime mover. The main power source of the machine is the prime mover (R175A diesel engine) with rated speed of 2,600 rpm and power rating of $4.84 \mathrm{~kW}$. The prime mover provides drives through a V-belt connected to the pulley attached to the shaft that drives both the threshing drum attached with set of beaters and the blower. The hopper is a component part where maize is introduced and move into the threshing unit to remove maize from the maize cob after which the separation of maize grain from cobs and chaffs takes place by a sieve. The cleaned maize grains were collected through the grain delivery chute using a collector while the chaffs and cobs were blown off with the aid of blower made of metal blade.

\subsection{Evaluation Method}

The performance evaluation of the fabricated thresher was carried out at the National Centre for Agricultural Mechanization (NCAM) Ilorin. The variety of maize used in this work is TZLComp1SynW-1. One of the major factors considered in this work was the moisture content of maize using the procedure developed by International Seed Testing Association (ISTA) [6]. Ten grams (10 g) of sample was taken using electrical weighing balance and oven dried at $130{ }^{\circ} \mathrm{C}$ for $4 \mathrm{~h}$. When constant weight was attained, the sample was removed and cooled in the desiccator. The weight of the sample was taken again to determine its final weight. Therefore, 9 $\mathrm{kg}$ of maize cob was fed into threshing machine through the hopper and moved directly to a unit where threshing operation was done. The chaffs and other dirty materials were blown off by the blower. The threshed maize grain was collected through the delivery chute using a collector and measured using weighing balance before packaging it in a safe material for further processing. This procedure was done in three replications for each of the three moisture contents of maize grain. Threshing efficiency and some other parameters evaluated were obtained using the equations below [7]:

$$
M C=\frac{M_{2}-M_{3}}{M_{2}-M_{1}} \times 100
$$

where $M C$ is the moisture content (\%); $M_{1}$ is the weight of sample before drying (g); $M_{2}$ is weight of sample + container before drying $(\mathrm{g}) ; M_{3}$ is weight of sample + container after drying (g).

$$
\text { Threshing efficiency }=\frac{M_{T}-M_{U}}{M_{T}} \times 100
$$

where $M_{T}$ is the total mass of maize fed into the machine; $M_{U}$ is the mass of the un-threshed maize.

$$
\text { Cleaning efficiency }(\%)=\frac{M_{C}}{M_{T}} \times 100
$$

where $M_{C}$ is the mass of cleaned maize delivered by the machine; $M_{T}$ is the total mass of the maize fed into the machine.

$$
\text { Threshing capacity }(\mathrm{kg} / \mathrm{h})=\frac{M_{T}}{T} \times 3600
$$

where $M_{T}$ is the total mass of the maize fed into the machine; $T$ is the total time taken to thresh maize cob.

$$
\text { Grain breakage }(\%)=\frac{M_{B}}{M_{t}} \times 100
$$

where $M_{B}$ is mass of broken maize cob; $M_{t}$ is the total mass of grain from which the broken maize was 
selected.

$$
\text { Quantity of chaff in the maize }(\%)=\frac{W_{c}}{M_{t}} \times 100
$$

where $W_{c}$ is the weight of chaff $(\mathrm{g}) ; M_{t}$ is the total weight of maize (g).

$$
\text { Fuel consumption }(\mathrm{L} / \mathrm{s})=\frac{q}{T}
$$

where $q$ is the amount of fuel (L) consumed by the thresher; $T$ is the time taken (s).

\section{Results and Discussion}

The pictorial view of the machine was shown in Fig. 1 where testing and evaluation was done.

Table 1 showed the result of the performance evaluation of maize cob thresher at three different stages of moisture contents $(15.81 \%, 16.79 \%$ and $17.10 \%)$ of maize cob, respectively. This was done to

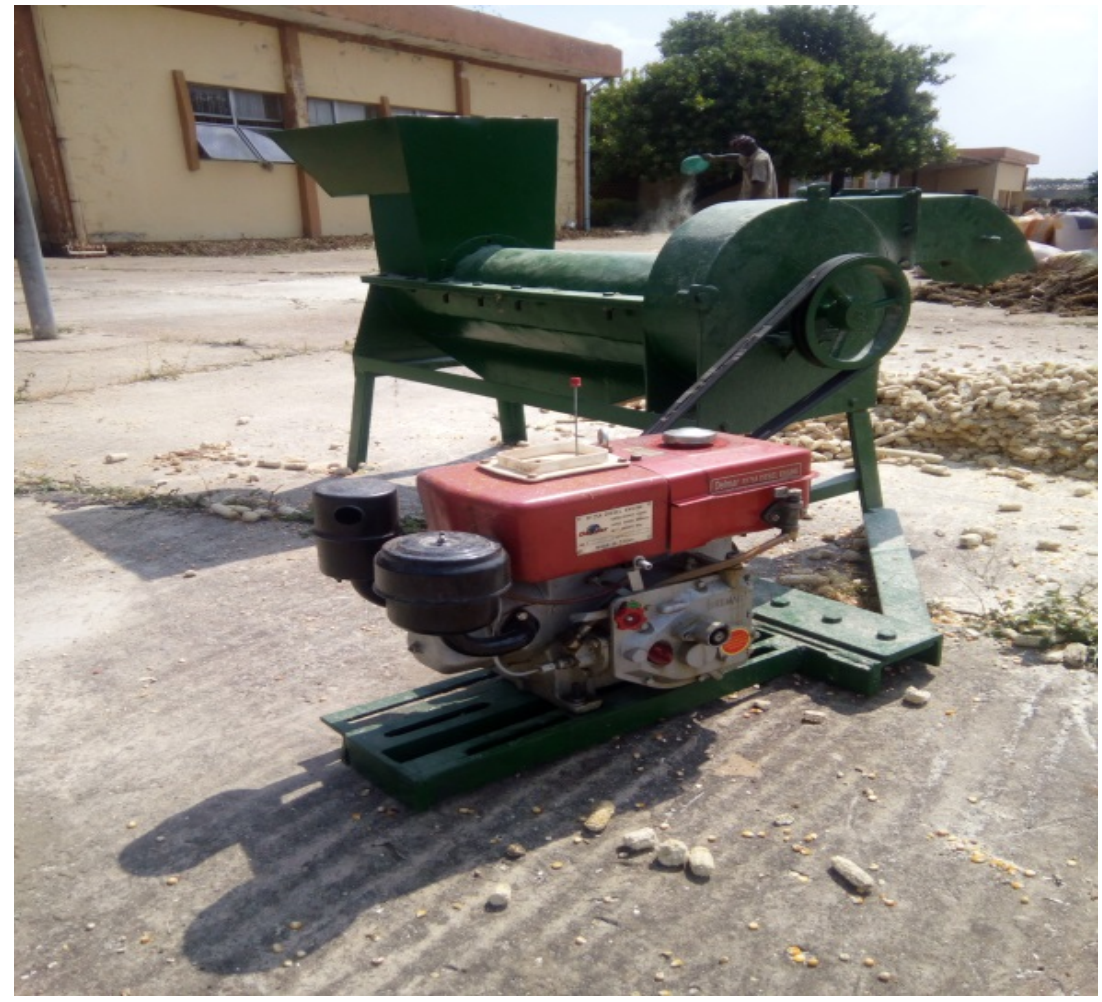

Fig. 1 Pictorial view of a maize thresher with prime mover.

\begin{tabular}{|c|c|c|c|c|c|c|c|c|c|c|}
\hline $\mathrm{S} / \mathrm{N}$ & $\begin{array}{l}\text { Moisture } \\
\text { contents } \\
(\%)\end{array}$ & $\begin{array}{l}\text { Quantity of } \\
\text { maize fed } \\
\text { into thresher } \\
(\mathrm{kg})\end{array}$ & $\begin{array}{l}\text { Quantity of } \\
\text { threshed } \\
\text { maize } \\
(\mathrm{kg})\end{array}$ & $\begin{array}{l}\text { Time } \\
\text { taken } \\
\text { (s) }\end{array}$ & $\begin{array}{l}\text { Threshing } \\
\text { capacity } \\
(\mathrm{kg} / \mathrm{h})\end{array}$ & $\begin{array}{l}\text { Threshing } \\
\text { efficiency } \\
\text { (\%) }\end{array}$ & $\begin{array}{l}\text { Cleaning } \\
\text { efficiency } \\
(\%)\end{array}$ & $\begin{array}{l}\text { Broken } \\
\text { grains ratio } \\
\text { (\%) }\end{array}$ & $\begin{array}{l}\text { Quantity of } \\
\text { chaff in the } \\
\text { threshed } \\
\text { maize (\%) }\end{array}$ & $\begin{array}{l}\text { Fuel } \\
\text { consumption } \\
(\mathrm{L} / \mathrm{s})\end{array}$ \\
\hline \multirow{4}{*}{1} & \multirow{3}{*}{15.81} & 9.00 & 8.00 & 45 & 720.00 & 99.69 & 88.90 & 0.87 & 2.86 & 0.0017 \\
\hline & & 9.00 & 8.10 & 42 & 771.43 & 99.70 & 90.00 & 0.80 & 2.29 & 0.0016 \\
\hline & & 9.00 & 8.15 & 42 & 771.43 & 99.81 & 90.56 & 0.85 & 2.43 & 0.0015 \\
\hline & Average & 9.00 & 8.08 & 43 & 754.20 & 99.73 & 89.82 & 0.84 & 2.53 & 0.0016 \\
\hline \multirow{4}{*}{2} & \multirow{3}{*}{16.79} & 9.00 & 8.00 & 44 & 736.36 & 99.69 & 88.90 & 0.80 & 3.29 & 0.0016 \\
\hline & & 9.00 & 8.05 & 46 & 704.35 & 99.68 & 89.44 & 0.78 & 2.86 & 0.0017 \\
\hline & & 9.00 & 8.10 & 42 & 771.43 & 99.67 & 90.00 & 0.80 & 3.20 & 0.0015 \\
\hline & Average & 9.00 & 8.05 & 44 & 737.38 & 99.68 & 89.45 & 0.79 & 3.12 & 0.0016 \\
\hline \multirow{4}{*}{3} & \multirow{3}{*}{17.10} & 9.00 & 8.00 & 45 & 720.00 & 99.14 & 88.90 & 0.70 & 3.37 & 0.0017 \\
\hline & & 9.00 & 7.90 & 44 & 736.36 & 99.22 & 87.78 & 0.67 & 3.49 & 0.0017 \\
\hline & & 9.00 & 7.95 & 46 & 704.34 & 99.12 & 88.33 & 0.73 & 3.63 & 0.0017 \\
\hline & Average & 9.00 & 7.95 & 45 & 720.23 & 99.16 & 88.34 & 0.70 & 3.50 & 0.0017 \\
\hline
\end{tabular}

Table 1 Result for the performance evaluation of a motorized maize cob thresher. 
Table 2 ANOVA result for the effect of three different moisture contents on the performance evaluation of a motorized maize thresher at $5 \%(p \leq 0.05)$ level of significance.

\begin{tabular}{|c|c|c|c|c|c|c|}
\hline & & Sum of squares & $\mathrm{df}$ & Mean square & $F$ & Sig. \\
\hline \multirow{3}{*}{$\begin{array}{l}\text { Threshed maize } \\
\text { (kg) }\end{array}$} & Treatment (moisture content \% ) & 0.029 & 2 & 0.014 & 4.000 & 0.079 \\
\hline & Error & 0.022 & 6 & 0.004 & & \\
\hline & Total & 0.051 & 8 & & & \\
\hline \multirow{3}{*}{$\begin{array}{l}\text { Threshing capacity } \\
(\mathrm{kg} / \mathrm{h})\end{array}$} & Treatment (moisture content \% ) & $1,739.473$ & 2 & 869.737 & 1.153 & 0.377 \\
\hline & Error & $4,527.509$ & 6 & 754.585 & & \\
\hline & Total & $6,266.982$ & 8 & & & \\
\hline \multirow{3}{*}{$\begin{array}{l}\text { Threshing efficiency } \\
\text { (\%) }\end{array}$} & Treatment (moisture content \% ) & 0.602 & 2 & 0.301 & 123.127 & 0.000 \\
\hline & Error & 0.015 & 6 & 0.002 & & \\
\hline & Total & 0.617 & 8 & & & \\
\hline \multirow{3}{*}{$\begin{array}{l}\text { Cleaning efficiency } \\
\text { (\%) }\end{array}$} & Treatment (moisture content \% ) & 3.572 & 2 & 1.786 & 4.030 & 0.078 \\
\hline & Error & 2.659 & 6 & 0.443 & & \\
\hline & Total & 6.230 & 8 & & & \\
\hline \multirow{3}{*}{$\begin{array}{l}\text { Broken grain ratio } \\
\text { (\%) }\end{array}$} & Treatment (moisture content \% ) & 0.030 & 2 & 0.015 & 19.600 & 0.002 \\
\hline & Error & 0.005 & 6 & 0.001 & & \\
\hline & Total & 0.035 & 8 & & & \\
\hline \multirow{3}{*}{$\begin{array}{l}\text { Quantity chaff in the } \\
\text { threshed maize } \\
\text { (\%) }\end{array}$} & Treatment (moisture content \% ) & 1.433 & 2 & 0.717 & 13.730 & 0.006 \\
\hline & Error & 0.313 & 6 & 0.052 & & \\
\hline & Total & 1.747 & 8 & & & \\
\hline \multirow{3}{*}{$\begin{array}{l}\text { Fuel consumption } \\
(\mathrm{L} / \mathrm{s})\end{array}$} & Treatment (moisture content \% ) & 0.000 & 2 & 0.000 & 1.500 & 0.296 \\
\hline & Error & 0.000 & 6 & 0.000 & & \\
\hline & Total & 0.000 & 8 & & & \\
\hline
\end{tabular}

know the suitable amount of moisture required for maize cob to be threshed in order to minimize the percentage grain loss during threshing. However, it was observed that threshing capacity and threshing efficiency of the machine at the moisture content of $15.81 \%, 16.79 \%$ and $17.10 \%$ were $754.20 \mathrm{~kg} / \mathrm{h}$, 99.73\%, $737.38 \mathrm{~kg} / \mathrm{h}, 99.68 \%$ and $720.23 \mathrm{~kg} / \mathrm{h}$, $99.16 \%$, respectively. The time taken during the evaluation of the machine at $15.81 \%$ moisture was less compare to $16.79 \%$ and $17.10 \%$ moisture, respectively. The percentages of broken grain ratio were $0.84 \%, 0.79 \%$ and $0.70 \%$ at moisture content of $15.81 \%, 16.79 \%$ and $17.10 \%$ of maize, respectively.

Table 2 showed that there was significant difference in threshing efficiency, amount of chaffs in the threshed maize and the broken grain ratio of the machine under the three different moisture contents of maize grain. In other words, the machine attained its highest threshing efficiency and threshing capacity at 15.81\% moisture as shown in Figs. 2 and 3, respectively. At $17.10 \%$ moisture content, the percentage broken grain ratio of the machine was minimal as shown in Fig. 4. This shows that the moisture content of maize cob has a vital role to play in threshing operation.

The performance of this machine was found to be in line with various research studies on the performance evaluation of maize thresher of different capacity. According to a report, a maize shelling machine has a threshing efficiency of $91.29 \%$ with an average shelling capacity of $55 \mathrm{~kg} / \mathrm{h}$ [8]. Also, in another report, a power operated maize Sheller has threshing efficiency and threshing capacity of $98.51 \%$ and $402.01 \mathrm{~kg} / \mathrm{h}$, respectively [9]. Furthermore, the efficiency of a maize shelling and grinding machine found to be $99.01 \%$ at $10 \%$ moisture content of maize [10]. Therefore, from this study, it was concluded that the highest threshing capacity and efficiency was obtained at $15.81 \%$ moisture content. This shows that the moisture content of maize played an important role in post-harvest operation, precisely in threshing to avoid deterioration of the grain. The higher the moisture 


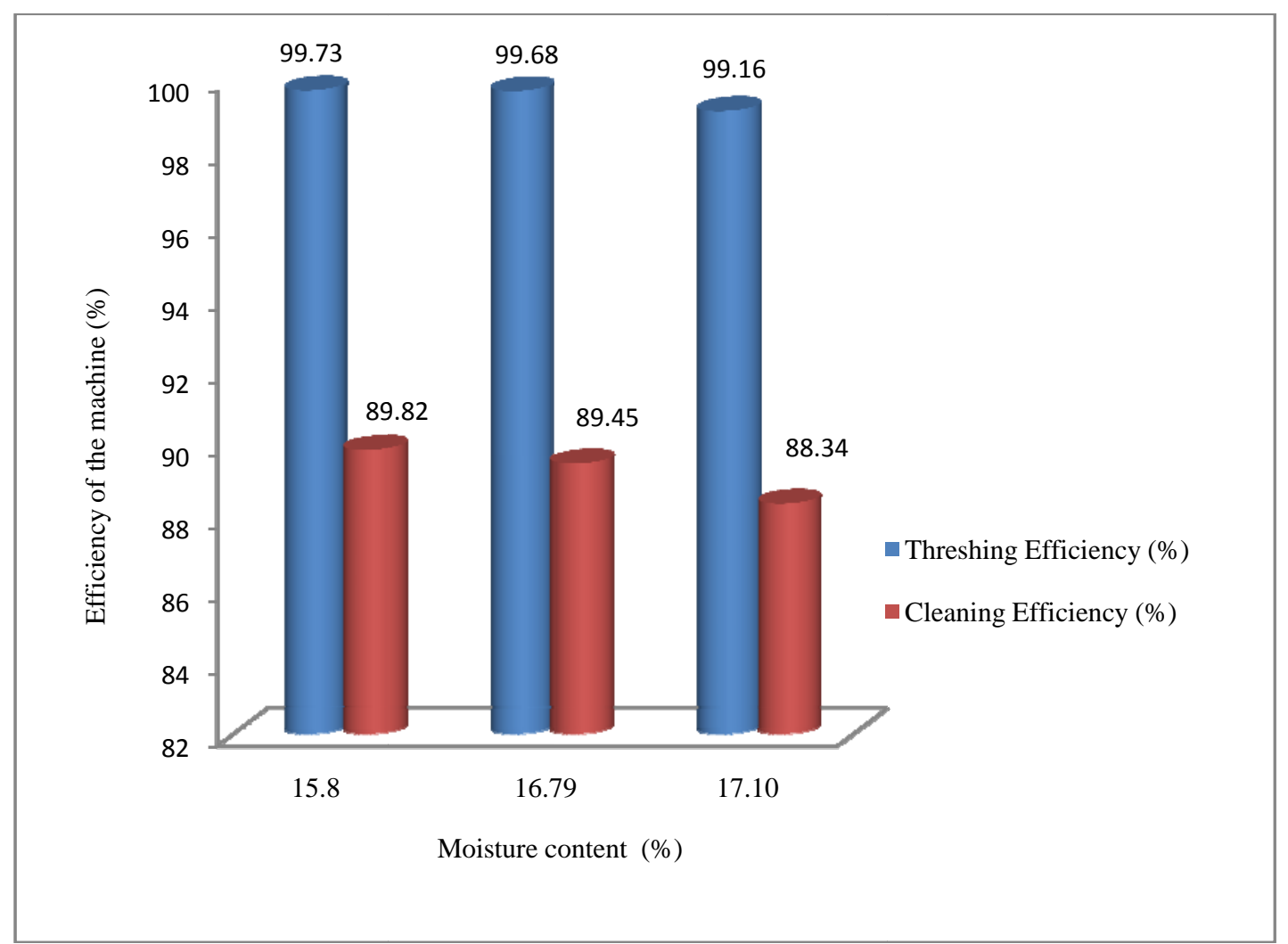

Fig. 2 Efficiency of the machine.

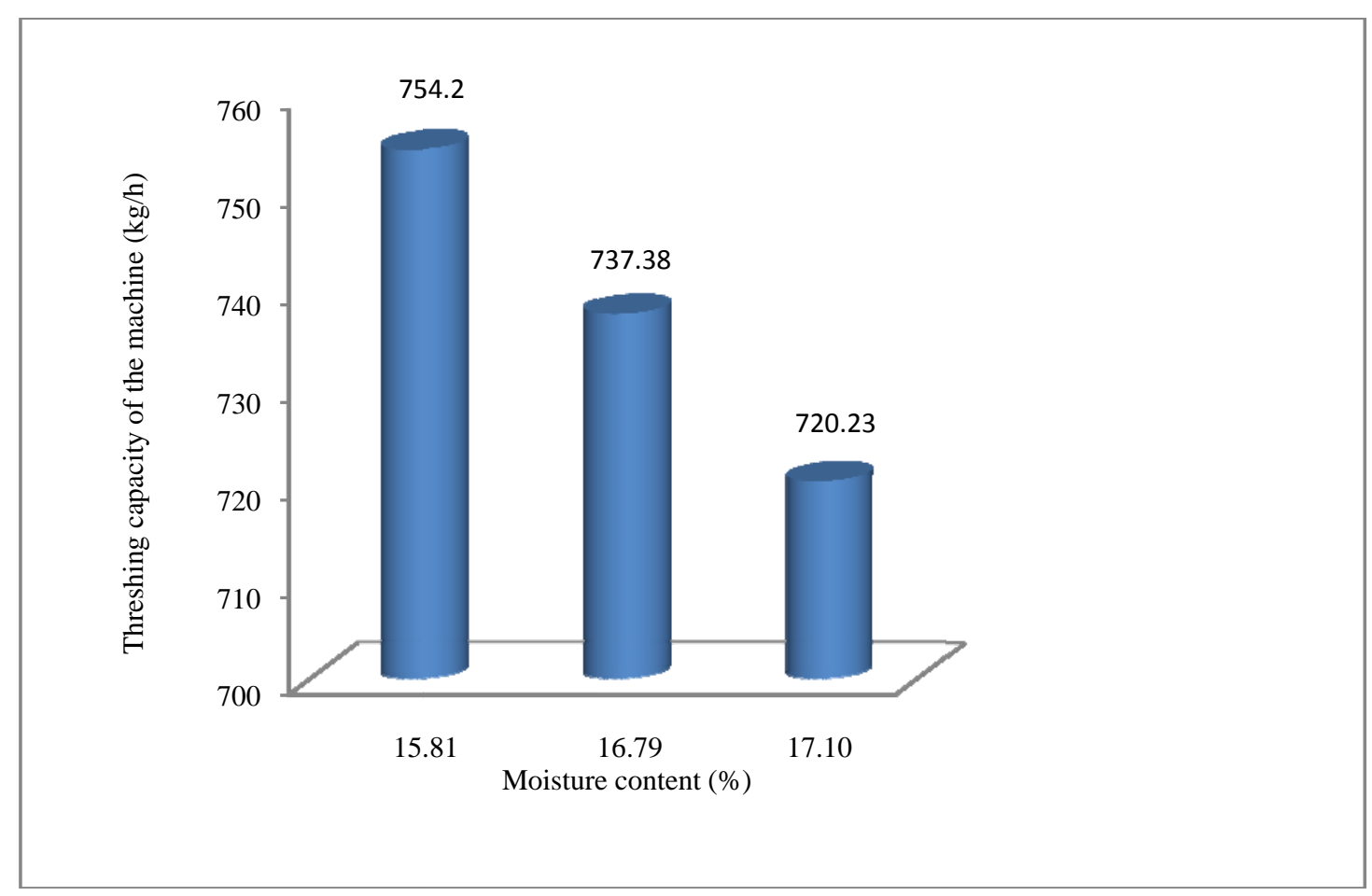

Fig. 3 Threshing capacity of machine. 


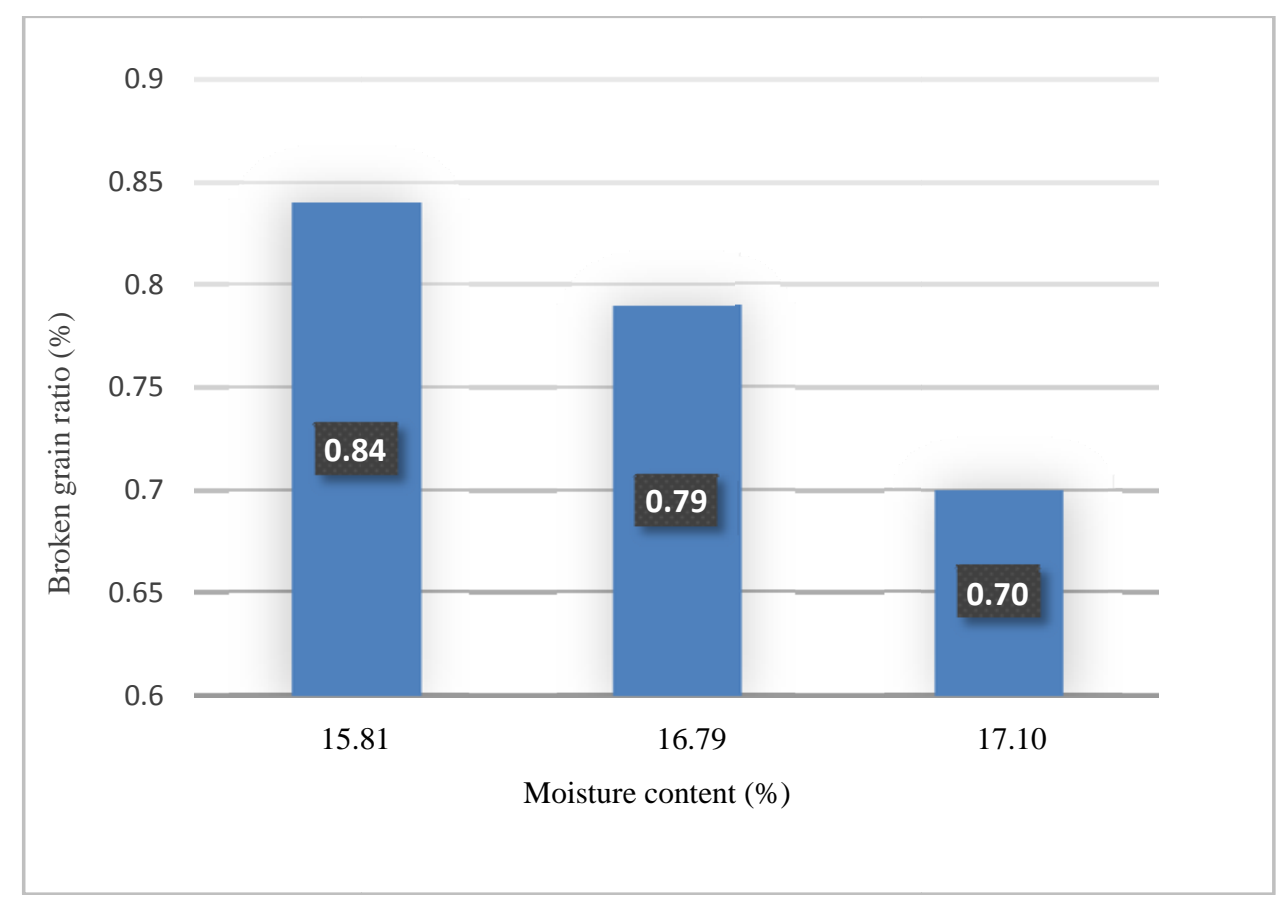

Fig. 4 Broken grain ratio against moisture content.

content of maize, the higher the force and energy required to thresh, the lower the moisture contents the easier and faster it is to be threshed.

Therefore, the machine performed satisfactorily under the three different moisture contents (15.81\%, $16.79 \%$ and $17.10 \%$ ) of maize cob.

\section{Conclusions}

The performance evaluation of a motorized maize thresher was carried out satisfactorily. The threshing capacity of the machine was 754.20, 737.38, 720.23 $\mathrm{kg} / \mathrm{h}$ at $15.81 \%, 16.79 \%$ and $17.10 \%$ of maize moisture content, respectively. It was observed that the machine performed better at low moisture content. In other words, there was significant difference in threshing efficiency, quantity of chaffs in threshed maize and the percentage broken grain ratio. The machine has minimal broken grain ratio at $17.10 \%$ moisture. The machine is cost effective, efficient and easy to operate and maintain. It reduces the human labor and stress involved in maize threshing and also reduces the time required for threshing operation. The machine is readily available and affordable for small, medium and large scale farmers in Nigeria.

\section{References}

[1] Aamir, H. K., Nasir, M. M., Muhammad, J. A., Azar, I. M. I., and Raja, T. M. 2014. "Estimation of Protein, Carbohydrate, Starch and Oil Contents of Indigenous Maize (Zea mays L.) Germplasm.” European Academic Research 2 (4): 5230-40.

[2] FAOSTAT. 2012. "World Maize Production and Fraction Produced in USA (Metric Tonnes).” Accessed November 9, 2018. http://faostat.fao.org.

[3] Knoema. 2018. "World Maize Production Quantity." Knoema. Accessed November 8, 2018. https://knoema.com/atlas/World/topics/Agriculture/Crops -Production-Quantity-tonnes/Maize-production.

[4] Oriaku, E. C., Agulanna, C. N., Nwannewuihe, H. U., Onwukwe, M. C., and Adiele, I. D. 2014. "Design and Performance Evaluation of a Corn De-cobbing and Separating Machine.” American Journal of Engineering Research 3 (6): 127-36.

[5] Aylor, D. E. 2002. "Setting Speed of Corn (Zea mays) Pollen.” Journal of Aero Goal Science 12 (7): 33-57.

[6] International Seed Testing Association (ISTA). 2012. Seed Testing Rule. ISTA Publication 8308, Barsserssorf, $\mathrm{CH}-\mathrm{Swizerland}$.

[7] Hamada, E., Hussain, S., and Saad, M. I. 2008. "Operating Factors Affecting Using Different Threshing Machine for Threshing Sunflower Heads.” In Proceedings of the 15th Annual Conference of the Misr Society of Agricultural Engineer on Agricultural Mechanization and Engineering, 251-70. 
[8] Azeez, T. M., Uchegbu, I. D., Babalola, S. A., and Odediran, O. O. 2017. "Performance Evaluation of a Developed Maize Sheller.” Journal of Advancement in Engineering and Technology 5 (2): 1-4.

[9] Naveenkumar, D. B., and Rajshekarappa, K. S. 2012. "Performance Evaluation of a Power Operated Maize
Sheller.” International Journal of Agricultural Engineering 5 (2): 172-7.

[10] Ugwu, K. C., and Omoruyi, A. 2016. "Development and Performance Evaluation of Maize Threshing and Grinding Machine.” American Journal of Engineering Research 5 (10): 24-9. 